\title{
Analisis Pengetahuan Masyarakat Kota Pekanbaru tentang Wisata Syariah
}

\author{
ZULKIFLI RUSBY \\ BOY SYAMSUL BAKHRI \\ MUHAMMAD YUSUF
}

\begin{abstract}
The background of this research emerged from the phenomenon that there is a global economic development at this time, namely the seven sectors of Islamic economy that have increased significantly. One of them is sharia tourism, whereas the sector carries the concept of halal in each of its products. In Pekanbaru City, sharia tourism experiences a very significant development with the vision of Pekanbaru City as Madani city. For this reason, the writers want to examine how the understanding of Pekanbaru City people about sharia tourism. The purpose of this study was to find out how well the enderstanding of Pekanbaru City people about sharia tourism. The method used in this study is a qualitative descriptive method with qualitative research. The population in this study was $1,038,118$ people. The sample is taken from the entire population of 100 people, with the sampling technique using the Slovin formula. Based on the results of research on the analysis of people's undersanding in Pekanbaru City about sharia tourism which was processed through respondents' answers, it can be concluded that $\mathrm{P}=83.86 \%$, which means that the analysis of the people's understanding in Pekanbaru City on sharia tourism showed "very strong / know" with a percentage of $81 \%$ $-100 \%$.
\end{abstract}

Keywords: Knowledge, Tourism, Syari'ah, Halal

\begin{abstract}
Abstrak: Latar Belakang penelitian ini adalah berangkat dari fenomena bahwa ada perkembangan ekonomi global saat ini yaitu ada tujuh sektor ekonomi syariah yang telah meningkat secara signifikan. Salah satunya adalah wisata syariah, dimana sektor itu mengusung konsep halal dalam setiap produknya, di Kota Pekanbaru wisata syariah mengalami perkembangan yang sangat signifikan dengan adanya visi Kota Pekanbaru sebagai kota Madani. Untuk itu peneliti ingin meneliti bagaimana pengetahuan masyarakat Kota Pekanbaru tentang wisata syaria. Tujuan dalam penelitian ini adalah untuk mengetahui sejauhmana pengetahuan masyarakat Kota Pekanbaru tentang wisata syariah. Metodologi yang digunakan dalam penelitian ini adalah metode deskriptif kualitatif dengan jenis penelitian kualitatif. Jumlah populasi dalam penelitian ini 1.038 .118 orang. Sampel diambil dari seluruh populasi yaitu 100 orang, dengan teknik pengambilan sampel adalah menggunakan rumus slovin. Berdasarkan hasil penelitian tentang analisis pengetahuan masyarakat Kota Pekanbaru tentang wisata syariah yang diolah melalui jawaban responden dapat disimpulkan $\mathrm{P}=83,86 \%$ yang berarti analisis pengetahuan masyarakat Kota Pekanbaru tentang wisata syariah banyak menjawab "sangat kuat/tahu" dengan persentase $81 \%-100 \%$.
\end{abstract}

Kata kunci: Pengetahuan, Wisata, Syari'ah, Halal 


\section{PENDAHULUAN}

Ekonomi syariah merupakan bagian terpenting dari ekonomi global saat ini. Ada tujuh sektor ekonomi syariah yang telah meningkat secara signifikan yaitu Perbankan Syariah, Lembaga Keuangan Syariah Non Bank, Investasi Syariah, Kosmetik, Fashion, Kuliner, Dan Wisata. Dimana setiap sektor itu mengusung konsep halal dalam setiap produknya.

Berdasarkan Laporan Akhir Kajian Pengembangan Wisata Syariah oleh Kementerian Pariwisata Tahun 2015, sektor ekonomi Islam yang telah mengalami pertumbuhan yang signifikan seperti produk lifestyle di sektor wisata yaitu wisata syariah. Sebagai industri tanpa asap, wisata terus mengalami perkembangan yang luar biasa dari yang bersifat konvensional (massal, hiburan dan hanya sightseeing) menjadi mengarah pada pemenuhan gaya hidup (lifestyle). Trend wisata syariah sebagai salah satu pemenuhan gaya hidup saat ini juga menjadi kekuatan wisata dunia yang mulai berkembang pesat.

Perkembangan konsep wisata syariah berawal dari adanya jenis wisata ziarah dan religi (pilgrims tourism/spiritual tourism). Dimana pada tahun 1967 telah dilaksanakan konferensi di Cordoba, Spanyol oleh World Tourism Organization (UNWTO) dengan judul "Tourism and Religions: $A$ Contribution to the Dialogue of Cultures, Religions and Civilizations" (UNWTO, 2011) (Unggul Priyadi, 2016: 92).

Data (BPS 2010), menunjukkan bahwa Indonesia saat ini sebagai negara dengan mayoritas penduduk muslim terbesar di dunia, dengan jumlah penduduk 207.176.162, oleh karena itu sudah sepatutnya Kementrian Pariwisata melihat hal ini dapat mengembangkan sektor wisata syariah.
Wisata syariah dipandang sebagai cara baru untuk mengembangkan wisata Indonesia yang menjunjung tinggi budaya dan nilai-nilai Islami. Pengembangan wisata syariah meliputi empat jenis komponen wisata, yaitu perhotelan, restoran, biro atau jasa perjalanan wisata dan spa. Selama ini wisata syariah dipersepsikan sebagai suatu wisata ke kuburan. Padahal, wisata syariah tidak diartikan seperti itu, melainkan wisata yang didalamnya berasal dari alam, budaya, ataupun buatan yang dibingkai dengan nilainilai Islam.

Kementrian Pariwisata menyatakan terdapat sembilan daerah yang memiliki potensi wisata syariah yang besar dan dijadikan daerah awal pengembangan wisata syariah di tanah air. Daerah tersebut adalah Sumatera Barat, Riau, Lampung, Banten, Jakarta, Jawa barat, Jawa Timur, Makassar, dan Lombok (Hery Sucipto, 2014: 159).

Untuk wilayah Sumatera, Khususnya di Provinsi Riau yang memiliki keunggulan di sektor wisata berbasis kebudayaan. Kebudayaan masyarakat Riau yang sangat kental dengan ciri khas melayu, akan menjadi terobosan baru sektor wisata. Dimana beberapa event budaya yang telah dilaksanakan di beberapa kabupaten yang ada di Riau ternyata mampu meningkatkan kunjungan wisatawan baik lokal maupun mancanegara.

Provinsi Riau memiliki 12 kabupaten/kota dengan pusat pemerintahannya adalah kota Pekanbaru yang merupakan kota yang terbesar di Provinsi Riau, sekaligus kota perdagangan dan jasa, termasuk kota dengan tingkat pertumbuhan, migrasi dan urbanisasi yang tinggi, dengan jumlah penduduk 1.038.118,dengan jumlah penduduk muslim 85,94 \% dari total penduduk kota Pekanbaru (BPS, 2015). 
Kota Pekanbaru juga memiliki beberapa destinasi wisata yang telah dikenal masyarakat setempat dan masyarakat luar kota Pekanbaru, yaitu (Visit Riau, 2014): (1) Wisata religi mesjid Agung An-Nur; (2) Wisata sejarah dan Religi di Mesjid Senapelan; (3) Wisata dakwah desa Okura; (4) Balai adat Riau; (5) Destinasi wisata Danau Buatan Lembah Sari; dan (6) Objek wisata Alam Mayang.

Sebagian masyarakat kota Pekanbaru dengan penduduk 85,94\% muslimnya, masih ada yang belum mengetahui tentang wisata syariah bahkan wisata syariah masih asing terdengar pada masyarakat awam. Wisata syariah atau Halal Tourims adalah salah satu sistem wisata yang diperuntukkan bagi wisatawan muslim maupun non-muslim yang pelaksanaannya mematuhi aturan syariah.

Berdasarkan pemaparan diatas, oleh karena itu penulis tertarik untuk melakukan penelitian berdasarkan latar belakang yang dituangkan dalam bentuk karya ilmiah yang berjudul "Analisis Pengetahuan Masyarakat Kota Pekanbaru tentang Wisata Syariah".

Setelah dilihat dari uraian latar belakang masalah tersebut di atas, maka dapat dikemukakan rumusan masalah dalam penelitian ini adalah bagaimana pengetahuan masyarakat Kota Pekanbaru tentang wisata syariah?Adapun tujuan dalam penelitian ini adalah untuk mengetahui pengetahuan masyarakat Kota Pekanbaru tentang wisata syariah. Manfaat Penelitian ini diharapkan menambah wawasan dan referensi mengenai ilmu pengetahuan di bidang wisata syariah bagi pelaku usaha wisata khususnya wisata syariah, menambah wawasan dan referensi kepustakaan mengenai ilmu pengetahuan di bidang wisata syariah di kalangan masyarakat luas dan menambah pengetahuan bagi kalangan akademis, masyarakat umum dan lembaga yang terkait dengan wisata syariah di Kota Pekanbaru.

\section{KONSEP TEORI \\ Konsep Pengetahuan}

Pengetahuan adalah hasil pengindraan manusia, atau hasil tahu seseorang terhadap objek melalui indra yang dimilikinya (mata, hidumg, telinga, dan sebagainya. Dengan sendirinya, pada pengindraan sampai menghasilkan pengetahuan tersebut sangat dipengaruhi oleh intensitas perhatian dan persepsi terhadap objek. Sebagian besar pengetahuan seseorang diperoleh melalui indra penglihatan yaitu mata (Sinta Fitriani, 129:2011).

Dalam kamus besar Bahasa Indonesia (2011), pengetahuan adalah sesuatu yang diketahui berkaitan dengan proses pembelajaran. Proses belajar ini dipengaruhi berbagai faktor dari dalam, seperti motivasi dan faktor luar berupa sarana informasi yang tersedia, serta keadaan sosial budaya.

Menurut Abd. Rachman Assegaf pengetahuan diartikan sebagai daya mengingat (menyebutkan kembali) informasi sebelumnya. Pengetahuan juga diartikan sebagai kemampuan untuk mendefinisikan, mengurai, menghitung, mengidentifikasi, memberi tanda, mendaftar, mencocokan, menyebut nama, membaca, mencatat, memproduksi, memilih menyatakan, dan melihat (Abd. Rachman Assegaf, 2011:77)

\section{Konsep Masyarakat}

Masyarakat adalah kesatuan sosial yang mempunyai ikatan kasih sayang erat. Individu dalam masyarakat merupakan kesatuan yang saling bergaul, saling berinteraksi 
sehingga membentuk kehidupan yang mempunyai jiwa. Jiwa masyarakat ini merupakan potensi yang berasal dari unsur-unsur masyarakat, meliputi pranata, status dan peran sosial (Esti Ismawati, 2012: 49)

Definisi lain dari Soerjono Soekanto mengatakan bahwa masyarakat merupakan kesatuan hidup manusia yang saling berinteraksi menurut suatu sistem adat-istiadat tertuentu yang bersifat kontinyu dan terikat oleh suatu rasa identitas bersama (Esti Ismawati, 2012: 49).

Dari definisi diatas dapat ditarik kesimpulan bahwa masyarakat adalah: (1) Manusia yang hidup bersama; (2) Bercampur untuk waktu yang cukup lama; (3) Mereka sadar bahwa mereka merupakan suatu kesatuan; dan (4) Mereka merupakan suatu sistem hidup bersama.

\section{Konsep Wisata}

Wisata dari bahasa Sansekerta adalah berulang kali/ berkali-kali sedangkan dalam bahasa Arab, wisata diistilahkan dengan kata as-siyahah yang diambil dalam ungkapan saha almaa' siyahah (air mengalir, mencair, meleleh. Ungkapan tersebut digunakan untuk menyebutkan air yang mengalir dan berjalan di atas permukaan tanah kata as-siyahah kemudian digunakan untuk konteks manusia, yang berarti berpergian di atas permukaan bumi dalam rangka ibadah, meningkatkan keshalehan, atau tanpa tujuan apapun.

Wisata menurut UU No,. 9/1990 tentang Kepariwisataan didefinisikan sebagai kegiatan perjalanan yang dilakukan secara sukarela dan bersifat sementara, serta perjalanan itu sebagian atau seluruhnya bertujuan untuk menikmati objek dan daya tarik wisata. Sedangkan pariwisata segala sesuatu yang berhubungan dengan wisata, termasuk pengusahaan objek dan daya tarik wisata serta usahausaha yang terkait dibidang tersebut (Bagyono, 2014:12).

Secara definitif, berdasarkan Undang-Undang No. 10/2009 tentang kepariwisataan, yang dimaksud dengan pariwisata adalah berbagai macam kegiatan yang didukung oleh berbagai fasilitas serta layanan yang disediakanmasyarakat, pengusaha, pemerintah, dan pemerintah daerah.

Pariwisata atau tourims adalah aktivitas yang berhubungan dengan perjalanan untuk rekreasi, berlibur, melancong, atau turisme. Objek pariwisata dapat berupa tempattempat bersejarah atau lokasi-lokasi alam yang indah dan atraktif. Dengan kata lain, pariwisata atau turisme adalah suatu perjalanan yang dilakukan untuk aktivitas ini.

\begin{tabular}{lrr}
\multicolumn{1}{c}{ Pariwisata } & dapat juga \\
memberikan & manfaat & dan \\
menyumbang antara lain: & (a)
\end{tabular}
Pelestarian budaya dan adat istiadat; (b) Peningkatan kecerdasan masyarakat; (c) Terjaganya suberdaya alam dan lingkungan lestari; dan (d) Terpeliharanya peninggalan kuno dan warisan masa lalu.

\section{Syariah}

Kata syariah berasal dari kata syara'a al-syai berarti menjelaskan sesuatu, atau ia ambil dari kata alsyir'ah dan al-syari'ah dengan arti tempat sumber mata air yang tidak pernah terputus. Secara leksikal berarti "jalan ke tempat pengairan" "jalan yang harus diikuti" atau "tempat lalu air di sungai". Arti terakhir ini digunakan orang Arab sampai sekarang untuk maksud kata "syariah". (Ahmad Fathoni Ramli, 73: 2016)

Secara bahasa, syariah berarti jalan yang dilewati untuk menuju sumber air. Kata syariah juga digunakan untuk menyebut madzhab 
atau ajaran agama. Dengan lebih ringkas, syariah berarti aturan dan undang-undang. Aturan disebut syariah/syariat, karena sangat jelas, dan mengumpulkan banyak hal. Ada pula yang mengatakan, aturan ini disebut syariah, karena dia menjadi sumber yng didatangi banyak orang untuk mengambilnya.

Secara istilah, syariah adalah semua aturan yang diturunkan Allah untuk para hambanya, baik terkai masalah akidah, ibadah muamalah, adab, maupun akhlak. Baik terkait hubungan makhluk dengan Allah, maupun hubungan antar-sesama makhluk. Allah SWT berfirman:

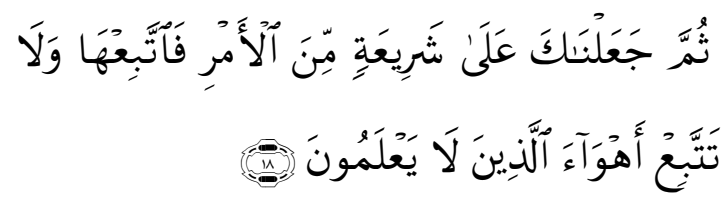

Artinya: "Kemudian aku jadikan kamu berada di atas suatu syariat (peraturan dari urusan (agama itu), maka ikutlah syariat itu dan jangan lah kau ikuti keinginan orang-orang yang tidak mengetahui" (Q.S Al-Jatsiyah:18).

Syariah Islamiayah adalah suatu aturan yang mencangkup seluruh aspek kehidupan. Oleh karena itu, syariah Islamiyah menetapkan jalan keimanan bagi manusia, juga menjelaskan tentang pokok-pokok akidah dan mengatur hubungan manusia dengan Tuhannya. Syariat Islam juga memerintahkan kepada manusia untuk membersihkan jiwanya, dan mengatur hubungan antarsesama. Islam, sebagai agama tidaklah mungkin tidak memberikan pedoman hidup bagi seluruh manusia dalam seluruh aspek kehidupan.

\section{Wisata Syariah}

Dalam pandangan Islam, wisata syariah tidak bisa dilepaskan dari tiga pilar utama, yaitu iman, Islam, dan ihsan. Ketiga pilar ini sekaligus menjadi penyangga dan pijakan dari seluruh aktivitas wisata. Dengan demikian, aktivitas wisata dalam Islam serat dengan nilai-nilai (tangible) Keimanan, ketauhidan, dan ketakwaan kepada sang khalik, Allah SWT, yang telah menciptakan segala bentuk keindahan, baik yang berada di darat, laut, maupun udara. Segala bentuk keindahan tersebut merupakan kurnia Allah untuk hambanya yang harus disyukuri dan ditafakuri. (Juhaya S. Pradja, 133: 2012)

Wisata syariah dapat didefinisikan sebagai, upaya perjalanan atau rekreasi untuk mencari kebahagiaan yang tidak bertentangan dan menyalahi prinsip-prinsip ajaran Islam, serta sejak awal diniatkan untuk mengagumi kebesaran ciptaan Allah. Selain itu, perjalanan dengan tujuan tertentu juga diniatkan sebagai sebuah perjalanan syiar, setidaknya dengan melafalkan ayat-ayat suci, atau bertasbih mengagumi keindahan alam sekitar, dan amalan positif lainnya sesuai dengan ajaran Islam serta memberikan manfaat bagi kehidupan umat manusia dan lingkungan sekitar (Bawazir, 2013: 21)

Definisi wisata syariah sangat luas dan bukan sekedar wisata religi. Wisata syariah adalah wisata yang berdasarkan pada nilai-nilai syariah Islam. Konsumen bukan hanya orang Islam, tetapi juga orang-orang nonMuslim yang ingin menikmati kearifan lokal seperti yang selalu dianjurkan World Tourism Organization (WTO).

Semua komponennya dibingkai dengan nilai-nilai Islam. Dalam hal ini dapat diihat perbedaan wisata syariah, wisata religi dan wisata konvensional pada tabel sebagai berikut: 
Tabel 1

Perbandingan Wisata Syariah dengan Wisata Konvensional dan Wisata Religi

\begin{tabular}{|c|c|c|c|c|}
\hline No & $\begin{array}{c}\text { Item } \\
\text { Perbandingan }\end{array}$ & $\begin{array}{c}\text { Wisata } \\
\text { Konvensional }\end{array}$ & Wisata Religi & Wisata syariah \\
\hline 1. & Objek & $\begin{array}{l}\text { Alam, budaya, } \\
\text { heritage, kuliner }\end{array}$ & $\begin{array}{l}\text { Tempat ibadah, } \\
\text { peningalan sejarah }\end{array}$ & Semuanya \\
\hline 2 & Tujuan & Menghibur & $\begin{array}{l}\text { Meningkatkan } \\
\text { spiritualitas }\end{array}$ & $\begin{array}{l}\text { Meningkatkan spriit } \\
\text { religiusitas dengan } \\
\text { cara menghibur }\end{array}$ \\
\hline 3 & Guide & $\begin{array}{lr}\text { Memahami } & \text { dan } \\
\text { menguasai } & \\
\text { informasi sehingga } \\
\text { bisa } & \text { menarik } \\
\text { wisatawan } & \\
\text { terhadap } & \text { objek } \\
\text { wisata } & \end{array}$ & $\begin{array}{l}\text { Menguasai sejarah } \\
\text { tokoh dan lokasi yang } \\
\text { menjadi objek wisata }\end{array}$ & $\begin{array}{lr}\text { Membuat } & \text { turis } \\
\text { tertarik pada } & \text { objek } \\
\text { sekaligus } & \\
\text { membangkit } & \text { spiriit } \\
\text { religiusitas } & \\
\text { wisatawan. } & \text { Mempu } \\
\text { menjelaskan } & \text { fungsi } \\
\text { dan peran } & \text { syariah } \\
\text { dalam membentuk } & \text { kebahagiaan dan } \\
\text { kepuasan r batin } & \text { dalam kehidupan } \\
\text { manusia } & \end{array}$ \\
\hline 4. & Target & $\begin{array}{l}\text { Menyentuh } \\
\text { kepuasan dan } \\
\text { kesenangan yang } \\
\text { berdimenasi nafsu, } \\
\text { semata-mata hanya } \\
\text { untuk hiburan }\end{array}$ & $\begin{array}{l}\text { Aspek spiritual yang } \\
\text { bisa menenangkan } \\
\text { jiwa. Semata-mata } \\
\text { mencari ketentraman } \\
\text { batin }\end{array}$ & $\begin{array}{l}\text { Memenuhi keinginan } \\
\text { dan kesenangan serta } \\
\text { menumbuhkan } \\
\text { kesadaran beragama }\end{array}$ \\
\hline 5 & Fasilitas Ibadah & Sekedar pelengkap & $\begin{array}{l}\text { Menjadi bagian yang } \\
\text { menyatu dengan } \\
\text { objek wisata }\end{array}$ & $\begin{array}{l}\text { Menjadi bagian yang } \\
\text { menyatu } \\
\text { objek pariwisata, } \\
\text { ritual peribadatan } \\
\text { menjadi paket bagian } \\
\text { hiburan }\end{array}$ \\
\hline 6 & Kuliner & Umum & Umum & Spesifik halal \\
\hline 7 & $\begin{array}{l}\text { Relasi dengan } \\
\text { masyarakat } \\
\text { dilingkungan } \\
\text { objek wisata }\end{array}$ & $\begin{array}{l}\text { Komplementer dan } \\
\text { semata-mata } \\
\text { mengejar } \\
\text { keuntungan }\end{array}$ & $\begin{array}{l}\text { Interaksi berdasar } \\
\text { pada nilai Religius }\end{array}$ & $\begin{array}{l}\text { Interaksi berdasar } \\
\text { pada prinsip-prinsip } \\
\text { syariah }\end{array}$ \\
\hline 8 & $\begin{array}{l}\text { Agenda } \\
\text { Perjalanan }\end{array}$ & Mengabaikan waktu & $\begin{array}{l}\text { Peduli } \\
\text { perjalanan }\end{array}$ & $\begin{array}{l}\text { Memperhatikan } \\
\text { waktu }\end{array}$ \\
\hline
\end{tabular}

Sumber: Panduan Wisata Syariah, Hery Sucipto, 2014

Dalam konteks wisata agama, masyarakat Indonesia selama ini lebih mengenal wisata religi atau religius (untuk umat Muslim) dan wisata rohani (biasanya untuk kalangan Nasrani atau wisata non-Muslim misalnya mengunjungi objek bersejarah agam mereka seperti gereja, wihara, kelenteng, makam orang-orang yang dianggap suci oleh penganut non-Muslim. 
Wisata religius terkait erat dengan agama sebagai motif seseorang dalam melakukan perjalanan rekreasi atau melancong. Setiap orang memiliki motif yang berbeda dalam melakukan perjalanan rekreasi tersebut. Apabila niat dalam hatinya bersifat tujuan Islami yang diridhai Allah dan sejalan dengan Agama maka perjalanan tersebut dapat disebut dengan wisata religius. Apalagi objek-objek yang dituju adalah objek-objek yang bersejarah dan berkaitan erat dengan keislaman.

\section{Pandangan dan Dasar Hukum Islam Tentang Wisata Syariah}

Dasar hukum penyelengaraan wisata syariah diatur dalam Fatwa DSN-MUI No: 108/DSN-MUI/X/2016 tentang Pedoman Penyelenggaraan Pariwisata Berdasarkan Prinsip Syariah.

Ada banyak dalil Al-Qur'an maupun sunnah Nabi berkaitan dengan pariwisata ini. Berikut dalil normatif dalam Islam tentang pariwisata, Allah SWT berfirman:

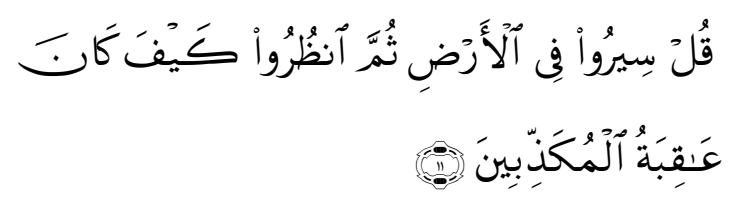

Artinya: "Katakanlah (Wahai Muhammad): "berjalanlah di muka bumi ini, kemudian perhatikanlah kesudahan orang-orang yang mendustakan itu." (QS AlAn'am:11).

Saking pentingnya melakukan perjalanandi muka bumi ini (melancong) dengan tujuan untuk mecari pelajaran dan hikmah, Allah SWT. Mengulangi ayat yang nyaris sama di surah yang berbeda.

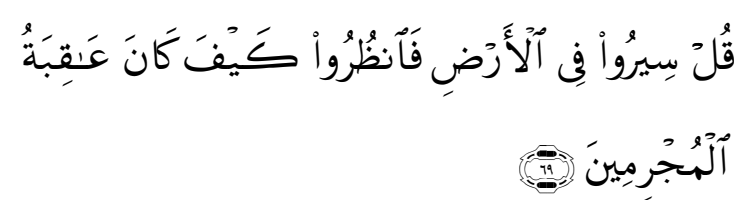

Artinya: "Katakanlah: "berjalanlah kamu (di muka) bumi, lalu perhatikanlah bagaimana akibat orangorang yang berdosa." (QS An-Naml:69)

Pada ayat pertama, Allah menganjurkan manusia melakukan perjalanan di muka bumi ini guna menemukan jawaban dan bukti bahwa orang-orang yang mendustakan kebenaran Tuhan ditimpa azab yang pedih. Pada ayat berikutnya, Allah menganjurkan manusia untuk melakukan perjalanan guna menemukan jawaban dan bukti bahwa hidup orang-orang yang berdosa berakhir dengan malang. Intinya, melancong atau berwisata memiliki tujuan spiritual, yakni untuk meningkatkan keimanan kepada tuhan dan mengakui kebesarannya.

Tidak hanya untuk mencari hikmah kehidupan, berwisata dianjurkan oleh Islam dengan tujuan untuk mengagumi keindahan alam, supaya jiwa menjadi tenang. Wisata dalam islam adalah sebuah safar atau traveling untuk merenungi keindahan dan ciptaan Allah SWT. Menikmati keindahan alam umtuk menguatkan keimanan dan motivasi diri untuk terus menunaikan kewajiban hidup. (Heri Sucipto: 2013: 50)

Refresing sangat diperlukan oleh jiwa agar selalu tumbuh semangat baru. Allah SWT, berfirman:

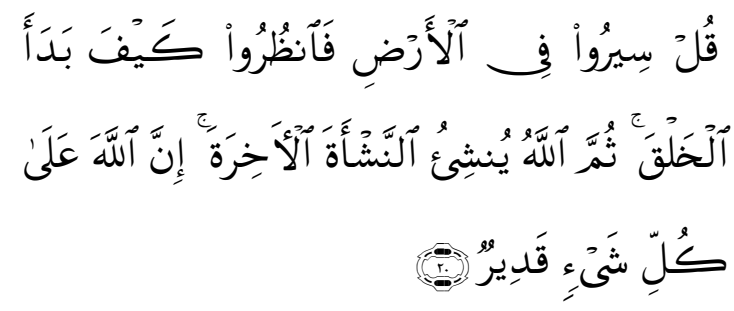


Artinya: "Katakanlah: "Berjalanlah di (muka) bumi, maka perhatikanlah bagaimana Allah menciptakan (manusia) dari permulaannya, kemudian Allah menjadikannya sekali lagi. Sesungguhnya Allah Maha Kuasa atas segala sesuatu." (QS Al-Ankabut:20)

Adapun Hukum asal perjalanan wisata adalah mubah alias diperbolehkan. Namun, asal ini dapat berubah karena adanya faktorlain yang menghalanginya. Disebut mubah (diperbolehkan), jika wisata ini semata-mata hanya untuk mencari hiburan dan kesenangan jiwa, selama di tempat tujuan wisata tidak terjadi kemaksiatan dan dekadensi moral secara terang-terangan. Namun, perlu diingat hukum mubah ini dapat berubah karena ada sebab lain yang terjadi. (Tohir Bawazir, 2013: 15).

\section{Potensi Provinsi Riau dalam Industri Wisata syariah}

Di Indonesia wisata syariah memiliki potensi yang sangat besar, dalam segi pariwisata alam dan budaya, pada pemerintahan Presiden Joko Widodo yang akan mengembangkan 4 destinasi pariwisata yakninya: Mandalika (Lombok), Labuan Bajo (NTT), Wakatobi (Sulawesi Tenggara), Danau Toba, Kepulauan Seribu, Candi Borobudur, Tanjung Lesung Belitung. Secara keseluruhan, di Indonesia ada sembilan destinasi wisata yang mempunyai potensi untuk dipromosikan sebagai destinasi wisata syariah yaitu Sumatera Barat, Riau, Lampung, Banten, Jakarta, Jawa Timur, Makassar, dan Lombok.

Khususnya di Provinsi Riau yang memiliki keunggulan di sektor wisata berbasis kebudayaan. Kebudayaan masyarakat Riau yang sangat kental dengan ciri khas melayu, akan menjadi terobosan baru sektor wisata. Dimana beberapa event budaya yang telah dilaksanakan dibeberapa kabupaten yang ada di Riau ternyata mampu meningkatkan kunjungan wisatawan baik lokal maupun mancanegara.

Provinsi Riau memiliki 12 kabupaten/kota dengan pusat pemerintahannya adalah Kota Pekanbaru, yang merupakan kota perdagangan dan jasa. Kota Pekanbaru memiliki fasilitas bandar udara internasional, yaitu bandar udara Sultan Syarif Kasim II dan terminal bus antar kota dan antar provinsi yaitu Bandar Raya Payung Sekaki, serta dua pelabuhan di Sungai Siak, yaitu Pelita Pantai dan Sungai Duku.

Kota Pekanbaru juga memiliki beberapa destinasi wisata yang telah dikenal masyarakat setempat dan masyarakat luar kota Pekanbaru. Sebagian masyarakat kota pekanbaru dengan penduduk mayoritas muslim dan terwujudnya sebagai kota madani, memiliki potensi yang sangat besar dalam penerapan wisata berbasis syariah.

Sebelum adanya penelitian ini, ada juga beberapa penelitian yang terkait, misalnya Ade Suherlan (2015) yang meneliti tentang "Persepsi Masyarakat Jakarta terhadap Islamic Tourism". Penelitian ini bertujuan untuk mengetahui persepsi dan preferensi masyarakat Jakarta terhadap wisata syariah. Hasil penelitian ini menunjukkan bahwa persepsi masyarakat Jakarta terhadap wisata syariah masih rendah kinerjanya padahal tingkat kepentingannya tinggi.

Rizka R (2016) meneliti tentang "Persepsi masyarakat tentang wisata syariah dan pengaruh terhadap minat berkunjung". Hasil penelitian ini adalah Variabel Persepsi Nilai dan Persepsi Merek memiliki pengaruh yang 
signifikan terhadap minat berkunjung konsumen dan Variabel Harga tidak berpengaruh secara signifikan. Variabel Persepsi Nilai, Variabel Merek dan Variabel Harga, secara bersama-sama atau simultan berpengaruh signifikan terhadap minat berkunjung konsumen.

Dengan melihat hasil penelitian diatas perbedaan penelitian terdahulu dengan penelitian ini adalah pada: (1) Subjek penelitiannya adalah masyarakat Kota Pekanbaru; (2) Objek penelitiannya adalah Pengetahuan Masyarakat Tentang wisata syariah; dan (3)Lokasi penelitiannya adalah wilayah Kota Pekanbaru.

\section{METODE}

Jenis penelitian yang digunakan dalam penelitian ini adalah jenis penelitian deskriptif. Jenis penelitian deskriptif adalah jenis penelitian yang disusun dalam rangka memberikan gambaran secara sistematis tentang informasi ilmiah yang berasal dari subjek atau objek penelitian. (Anwar Sanusi, $2011:$ 13)

Penelitian ini dilaksanakan di wilayah Kota Pekanbaru Provinsi Riau dan waktu penelitian dilaksanakan dari bulan Juli 2017 sampai bulan Oktober 2017.

Adapun yang menjadi subjek penelitian ini adalah masyarakat Kota Pekanbaru yang menetap dan berdomisili di wilayah Kota Pekanbaru. Sedangkan yang menjadi objek penelitian ini adalah pengetahuan masyarakat Kota Pekanbaru tentang wisata syariah.

Populasi adalah seluruh kumpulan elemen yang menunjukan ciri-ciri tertentu yang dapat digunakan untuk membuat kesimpulan. (Anwar Sanusi, 2011 : 87)

Adapun sebagai populasi dalam penelitian ini adalah masyarakat Kota Pekanbaru tahun 2015 yang berjumlah 1.038.118 orang (Sumber: BPS Kota Pekanbaru).

Dalam menentukan ukuran sampel penelitian, Slovin memasukan unsur kelonggaran ketidak telitian karena kesalahan pengambilan sampel yang masih dapat ditoleransi. Karena banyaknya jumlah populasi secara keseluruhan dari masyarakat Kota Pekanbaru tersebut. (Anwar Sanusi, 2011 : 87)

Tabel 2

Ukuran sampel perkecamatan di Kota Pekanbaru

\begin{tabular}{clcc}
\hline No & \multicolumn{1}{c}{ Kecamatan } & Jumlah & Sampel \\
\hline 1 & Tampan & 201.182 & 19 \\
\hline 2 & Payung Sekaki & 101.128 & 10 \\
\hline 3 & Bukit Raya & 109.381 & 11 \\
\hline 4 & Marpoyan Damai & 146.221 & 14 \\
\hline 5 & Tenayan Raya & 148.013 & 14 \\
\hline 6 & Lima Puluh & 44.481 & 5 \\
\hline 7 & Sail & 23.124 & 2 \\
\hline 8 & Pekanbaru Kota & 27.224 & 3 \\
\hline 9 & Sukajadi & 49.650 & 5 \\
\hline 10 & Senapelan & 38.340 & 4 \\
\hline 11 & Rumbai & 74.977 & 7 \\
\hline 12 & Rumbai Pesisir & 74.397 & $\mathbf{1 0 0}$ \\
\hline
\end{tabular}


Dari jumlah diatas, maka penulis melakukan pengambilan sampel. Adapun jumlah sampel ditentukan berdasarkan rumus Slovin (Riduwan,2009:65). Jadi dalam Penelitian ini ukuran sampelnya adalah sebanyak 100 orang.

Dari jumlah sampel tersebut kemudian ditentukan jumlah masing-masing sampel menurut tingkat (strata) dengan teknik pengambilan sampel mengunakan Proportionate Stratified Random Sampling, yaitu pengambilan sampel dari anggota populasi dan berstrata secara proposional (Riduwan, 2014: 28).

Dalam Penelitian inipenulis memperoleh data-data yang kongkrit yaitu data primer dan data skunder yang benar-benar mendukung dalam mengumpulkan data, beberapa teknik diantaranya yaitu kuesioner membuat sejumlah pernyataan tertulis yang diajukan kepada responden yang dianggap sampel yang terpilih.

Sumber data yang digunakan dalam penelitian ini terbagi dalam dua bagian, yaitu sebagai berikut: (a) Data Primer adalah data yang diperoleh peneliti dari sumber asli. Dalam hal ini, maka proses pengumpulan datanya perlu dilakukan dengan memperhatikan siapa sumber utama yang akan dijadikan objek penelitian. Yaitu berupa angket/kuesioner yang diisi oleh responden (Muhammad, 2008:103). Adapun data primer dalam penelitian ini adalah angket yang disebarkan kepada masyarakat yang berdimisili di Kota Pekanbaru; dan (b) Data Sekunder adalah sumber data yang diperoleh secara tidak langsung dan hanya melalui media perentara. Data ini diperoleh dari literaturliteratur yang berkaitan dengan judul yang penulis buat. Yaitu berupa jurnal, buku-buku yang terkait dan penelitian yang relevan dengan judul peneliti
(Muhammad, 2008:103). Adapun data skunder dalam penelitian ini adalah berupa literature-literatur yang berkaitan dengan pengetahuan masyarakat serta literature-literatur yang berkaitran dengan wisata syariah.

Untuk melengkapi data yang diperlukan dalam penelitian ini metode pengumpulan data yang digunakan adalah kuesioner (angket). Kuesioner (angket) merupakan tenik pengumpulan data yang dilakukan dengan memberikan seperangkat pernyataan atau pertanyaan tertulis kepada responden untuk dijawabnya. Kuesioner merupakan teknik pengumpulan data yang efisien bila peneliti tahu dengan pasti variabel yang akan diukur dan tahu apa yang diharapkan dari responden. (Sugiono, 2013:142)

Pengolahan data dilakukan setelah semua data terhimpun dan telah dapat gambara yang menyeluruh tentang objek penelitian. Pada penelitian kualitatif, pengolahan data secara umum dilaksanakan dengan melalui tahap memeriksa (editing), proses pemberian identitas (coding), dan proses pembeberan (tabulating) (Muhammad, 2008:205).

Untuk menjawab hipotesis dalam penelitian ini menggunakan analisis data deskriptif untuk menghitung persentase. Pengolahan data menggunakan program SPSS for Windows versi 23.0.

\section{HASIL DAN PEMBAHASAN Tinjauan Umum Kota Pekanbaru}

Nama Pekanbaru dahulunya dikenal dengan nama "Senapelan" yang saat itu dipimpin oleh seorang Kepala Suku disebut Batin. Daerah ini terus berkembang menjadi kawasan pemukiman baru dan seiring waktu 
berubah menjadi Dusun Payung Sekaki yang terletak di muara Sungai Siak.

Terus berkembang, Payung Sekaki atau Senapelan memegang peranan penting dalam lalu lintas perdagangan. Perkembangan Senapelan sangat erat dengan Kerajaan Siak Sri Indra Pura. Semenjak Sultan Abdul Jalil Alamudin Syah menetap di Senapelan, beliau membangun Istana di Kampung Bukit dan diperkirakan Istana tersebut terletak disekitar lokasi Mesjid Raya sekarang. Sultan kemudian berinisiatif membuat pekan atau pasar di Senapelan namun tidak berkembang. Kemudian usaha yang dirintis tersebut dilanjutkan oleh putranya Raja Muda Muhammad Ali yang bergelar Sultan Muhammad Ali Abdul Jalil Muazamsyah meskipun lokasi pasar bergeser di sekitar Pelabuhan Pekanbaru sekarang.

Kota Pekanbaru terletak antara $101^{\circ} 14^{\prime}$ - 1013' Bujur Timur dan $0^{\circ} 25^{\prime}$ - $0^{\circ} 45^{\prime}$ Lintang Utara. Dengan ketinggian dari permukaan laut berkisar 5 - 50 meter. Permukaan wilayah bagian utara landai dan bergelombang dengan ketinggian berkisar antara 5 - 11 meter.

Berdasarkan

Peraturan Pemerintah No. 19 Tahun 1987 Tanggal 7 September 1987 Daerah Kota Pekanbaru diperluas dari $\pm 62,96$ $\mathrm{Km}^{2}$ menjadi $\pm 446,50 \mathrm{Km}^{2}$, terdiri dari 8 Kecamatan dan 45 Kelurahan/Desa. Dari hasil pengukuran/pematokan di lapangan oleh BPN Tk. I Riau maka ditetapkan luas wilayah Kota Pekanbaru adalah 632,26 $\mathrm{Km}^{2}$.Untuk lebih terciptanya tertib pemerintahan dan pembinaan wilayah yang cukup luas, maka dibentuklan Kecamatan Baru dengan Perda Kota Pekanbaru No. 4 Tahun 2003 menjadi 12 Kecamatan dan Kelurahan/Desa baru dengan Perda tahun 2003 menjadi 58 Kelurahan/Desa.

Kota Pekanbaru berbatasan dengan daerah Kabupaten/Kota: (a)
Sebelah Utara : Kabupaten Siak dan Kabupaten Kampar; (b) Sebelah Selatan: Kabupaten Kampar dan Kabupaten Pelalawan; (c) Sebelah Timur: Kabupaten Siak dan Kabupaten Pelalawan; dan (d) Sebelah Barat: Kabupaten Kampar.

Kota Pekanbaru pada umumnya beriklim tropis dengan suhu udara maksimum berkisar antara 34,1으 $\mathrm{C}$ $35,6^{\circ} \mathrm{C}$ dan suhu minimum antara 20,2ㅇ C - 23,0으 C. Curah hujan antara 38,6 - 435,0 mm/tahun.

\section{Wisata Syariah di Kota Pekanbaru}

Riau punya beragam keunggulan wisata halal seperti objek wisata yang bernuansa Islam sebagai ciri khas budaya Melayu. Khusunya Pekanbaru saat ini wista syariah Masjid Raya Annur dan wisata desa Okura yang menjadi tujuan utama wisata religi di Riau, dengan suasana Islami dan memberikan pengalaman berwisata syariah bagi para pengunjungnya. Beberapa hal yang perlu diperhatikan pada pelayanan wisata halal seperti memastikan setiap menu di hotel bagi tamu sudah terjamin halal dan bebas dari bahan baku non halal. Untuk fasilitas publik terkait wisata juga akan diupayakan pengelompokan yaitu bagi wisatawan berkeluarga atau dengan muhrim, dan non muhrim sehingga tidak bercampur antar keduanya.

\section{Deskripsi Data \\ Identitas Responden}

Identitas responden dalam kegiatan penelitian sangat penting untuk mengetahui jenis kelamin, kecamatan, usia, pendidikan dan pekerjaan yang dijadikan sampel. Dalam penelitian ini, responden yang berjenis kelamin perempuan lebih banyak dari pada jenis kelamin lakilaki, yaitu berjumlah 57 orang (57\%) sedangkan yang laki-laki berjumlah 43 orang (43\%). Jumlah responden 
dengan usia 17-23 berjumlah 27 orang (27\%), usia 24-24 berjumlah 18 orang (18\%), usia 30-39 berjumlah 27 orang (27\%), usia $40-49$ berjumlah 20 orang (20\%) dan usia 50-70 berjumlah 8 orang $(8 \%)$.

\section{Analisis Data}

Penelitian ini merupakan penelitian deskriptif. Penelitian deskriptif adalah penelitian yang disusun dalam rangka memberikan gambaran secara sistematis tentang informasi ilmiah yang berasal dari subjek atau objek penelitian (Anwar Sanusi, 2014: 13).

Berikut hasil rekapitulasi dari 23 butir pernyataan melalui angket kepada responden yang telah dipermasalahkan pada penelitian ini.

Tabel 3

Rekapitulasi hasil angket tentang analisis pengetahuan masyarakat Kota Pekanbaru tentang wisata syariah

\begin{tabular}{|c|c|c|c|c|c|}
\hline \multirow{3}{*}{ NO } & \multicolumn{4}{|c|}{ Frekuensi } & \multirow{3}{*}{ Skor } \\
\hline & Benar & \multirow{2}{*}{$\%$} & Salah & \multirow{2}{*}{$\%$} & \\
\hline & 1 & & $\mathbf{0}$ & & \\
\hline 1 & 73 & 73 & 27 & 27 & 73 \\
\hline 2 & 84 & 84 & 16 & 16 & 84 \\
\hline 3 & 81 & 81 & 19 & 19 & 81 \\
\hline 4 & 75 & 75 & 25 & 25 & 75 \\
\hline 5 & 65 & 65 & 35 & 35 & 65 \\
\hline 6 & 63 & 63 & 37 & 37 & 63 \\
\hline 7 & 90 & 90 & 10 & 10 & 90 \\
\hline 8 & 83 & 83 & 17 & 17 & 83 \\
\hline 9 & 93 & 93 & 7 & 7 & 93 \\
\hline 10 & 96 & 96 & 4 & 4 & 96 \\
\hline 11 & 98 & 98 & 2 & 2 & 98 \\
\hline 12 & 63 & 63 & 37 & 37 & 63 \\
\hline 13 & 95 & 95 & 5 & 5 & 95 \\
\hline 14 & 95 & 95 & 5 & 5 & 95 \\
\hline 15 & 89 & 89 & 11 & 11 & 89 \\
\hline 16 & 86 & 86 & 14 & 14 & 86 \\
\hline 17 & 96 & 96 & 4 & 4 & 96 \\
\hline 18 & 95 & 95 & 5 & 5 & 95 \\
\hline 19 & 73 & 73 & 27 & 27 & 73 \\
\hline 20 & 66 & 66 & 34 & 34 & 66 \\
\hline 21 & 88 & 88 & 12 & 12 & 88 \\
\hline 22 & 88 & 88 & 12 & 12 & 88 \\
\hline 23 & 94 & 94 & 6 & 6 & 94 \\
\hline \multicolumn{5}{|c|}{ Total Skor responden } & 1.929 \\
\hline
\end{tabular}


Berdasarkan tabulasi di atas dapat di interpretasikan berdasarkan skor untuk mengetahui tingkat pengetahuan masyarakat Kota Pekanbaru tentang wisata syariah. Kriteria interpretasi skor yaitu: 1) Sangat Kuat, jika skor terletak antar 81\%-100\%; 2) Kuat, jika skor terletak antara 61\%-80\%; 3) Cukup Kuat, jika skor terletak antara 41\%-60\%; 4) Lemah, jika skor terletak antara 21\%-40\% dan 5) Sangat Lemah, jika skor terletak antar 0\%-20\%.

Dari tabel 12 di atas dapat diketahui skor yang diperolehdari responden adalah 1.929 sedangkan skor ideal (skor tertinggi) $=23 \times 1 \times$ $100=2300$. Dari data di atas dapat diketahui bahwa pengetahuan masyarakat Kota Pekanbaru tentang wisata syariah adalah tergolong sangat kuat $(1.929 / 2.300 \times 100 \%=83,86 \%)$. Berdasarkan beberapa dimensi dalam penelitian ini dapat dijabarkan sebagai berikut:

\section{Berdasarkan dimensi Objek}

Pada angket no.1 berjumlah 73 orang atau sebesar $73 \%$ yang menjawab benar atau tahu, kemudian yang menjawab salah 27 orang atau $27 \%$. Maka rata-rata para responden menjawab benar atau tahu pada pernyataan wisata syariah menawarkan objek wisata alam dalam produknya.

Pada angket no.2 yang menjawab benar atau tahu berjumlah 84 orang atau $84 \%$, kemudian yang menjawab salah 16 orang atau 16\%. Maka ratarata para responden menjawab benar atau tahu pada pernyataan wisata syariah menawarkan objek wisata budaya dalam produknya. Hala ini dapat dilihat pada wacana pemerintah provinsi Riau ataupun Kota Pekanbaru akan mengangkat wisata budaya melayu dalam destinasi wisata syariah.
Pada angket no. 3 yang menjawab benar atau tahu berjumlah 81 orang atau $81 \%$, kemudian yang menjawab salah/tidak tahu berjumlah 19 orang atau $19 \%$. Maka rata-rata para responden menjawab ya atau tahu pada pernyataan wisata syariah menawarkan objek wisata sejarah dalam produknya.

Pada angket no. 4 yang menjawab benar /tahu berjumlah 75 orang atau $75 \%$, kemudian yang menjawab salah/tidak tahu berjumlah 25 orang atau 25\%. Maka rata-rata para responden menjawab benar atau tahu pada pernyataan wisata syariah menawarkan wisata religi dalam produknya. Hal ini dapat dilihat masyarakat Kota Pekanbaru adalah mayoritas Islam dan memiliki tingkat religius yang tinggi.

Pada angket no. 5 yang menjawab benar atau tahu berjumlah 65 orang atau $65 \%$, kemudian yang menjawab salah/tidak tahu berjumlah 35 orang atau $35 \%$. Maka rata-rata para responden mengetahui atau menjawab benar pada pernyataan wisata syariah menawarkan objek wisata kuliner dalm pruduknya

Berdasarkan dimensi tujuan

Pada angket no 6 yang menjawab benar atau tahu berjumlah 63 orang atau $63 \%$, kemudian yang menjawab salah/ tidak tahu berjumlah 37 orang tau $37 \%$. Maka rata-rata para responden menjawab benar atau tahu pada pernyataan wisata syariah bertujuan menghibur wisatawan berdasarkan prinsip syariah.

Pada angket no.7 yang menjawab benar atau tahu berjumlah 90 orang atau $90 \%$, kemudian yang menjawab salah/tidak tahu berjumlah 10 orang atau $10 \%$. Maka rata-rata para responden menjawab benar atau tahu pada peryataan wisata syariah 
bertujuan meningkatkan spiritualitas bagi wisatawan.

Pada angket no 8 yang menjawab benar atau tahu berjumlah 83 orang atau $83 \%$, kemudian yang menjawab salah/ tidak tahu berjumlah 17 orang atau $17 \%$. Maka rata-rata para responden menjawab benar atau tahu pada pernyataan wisata syariah bertujuan untuk mengagumi kebesaran Allah SWT.

Berdasarkan dimensi target

Pada angket no.9 yang menjawab benar atau tahu berjumlah 93 orang atau 93\%, kemudian yang menjawab salah/tidak tahu berjumlah 7 orang atau $7 \%$. Maka rata-rata para responden menjawab benar atau tahu pada pernyataan wisata syariah dapat menyentuh kepuasan dan kesenangan bagi wisatawan.

Pada angket no.10 yang menjawab benar atau tahu berjumlah 96 orang atau 96\%, kemudian yang menjawab salah/tidak tahu berjumlah 4 orang atau 4\%. Maka rata-rata para responden menjawab benar atau tahu pada pernyataan wisata syariah dapat meningkatkan kesadaran beragama bagi wisatawan.

Pada angket no 11 yang menjawab benar atau tahu berjumlah 98 orang atau 98\%, kemudian yang menjawab salah/ tidak tahu berjumlah 2 orang atau $2 \%$. Maka rata-rata para responden yang menjawab benar atau tahu pada pernyataan wisata syariah dapat memberikan ketenangan bathin bagi wisatawan.

Pada angket no 12 yang menjawab benar atau tahu berjumlah 63 orang atau 63\%, kemudian yang menjawab salah/ tidak tahu berjumlah 37 orang atau $37 \%$ maka rata-rata para responden menjawab benar atau tahu pada pernyataan wisata syariah diperuntukan bagi kaum muslim dan non muslim. Hal ini dapat dilihat tidak adanya batasan seseorang kaum untukiberkunjung pada wisata syariah. Berdasarkan dimensi pemandu (guide) Pada angket no.13 yang menjawab benar atau tahu berjumlah 95 orang atau 95\%, kemudian yang menjawab salah/ tidak tahu berjumlah 5 orang atau 5\%. Maka rata-rata para responden menjawab benar atau tahu pada pernyataan pengetahuan yang luas tentang objek wisata syariah membuat wisatawan tertarik dalam wisata syariah.

Pada angket no. 14 yang menjawab benar atau tahu berjumlah 95 orang atau $95 \%$, kemudian yang menjawab salah/ tidak tahu berjumlah 5 orang atau $5 \%$. Maka rata-rata para responden menjawab benar atau tahu pada pernyataan pengetahuan yang luas tentang objek wisata syariah dapat membangkitkan sprit religius wisatawan.

Pada angket no. 15 yang menjawab benar atau tahu berjumlah 89 orang atau $89 \%$, kemudian yang menjawab salah/tidak tahu berjumlah 11 orang atau 11\%. Maka rata-rata para responden menjawab benar atau tahu pada pernyataan pengetahuan tentang peran dan fungsi syariah pada objek wisata dapat membentuk kebahagiaan dan kepuasan bathin pada wisatawan.

Berdasarkan dimensi fasilitas ibadah

Pada angket no. 16 yang menjawab benar atau tahu berjumlah 86 orang atau $86 \%$, kemudian yang menjawab salah/tidak tahu berjumlah 14 orang atau $14 \%$. Maka rata-rata para responden menjawab benar atau tahu pada pernyataan Fasailitas ibadah dalam wisata syariah menjadi bagian yang menyatu dengan objek wisata. Hal ini dapat dilihat fasilitas ibadah pada wisata syariah menjadi bagian pokok atau batang tubuh dari wisata syariah.

Pada angket no. 17 yang menjawab ya atau tahu berjumlah 96 
orang atau 96\%, kemudian yang menjawab salah/ tidak tahu berjumlah 4 orang atau 4\%. Maka rata-rata para responden menjawab benar atau tahu pada pernyataan beribadah dalam wisata syariah menjadi paket bagian dari hiburan.

\section{Berdasarkan dimensi kuliner}

Pada angket no. 18 yang menjawab benar atau tahu berjumlah 95 orang atau 95\%, kemudian yang menjawab salah/tidak tahu berjumlah 5 orang atau $5 \%$. Maka rata-rata para responden menjawab ya atau tahu pada pernyataan wisata syariah menyediakan wisata kuliner dengan spesifikasi halal.

Pada angket no. 19 yang menjawab benar atau tahu berjumlah 73 orang atau $73 \%$, kemudian yang menjawab salah/tidak tahu berjumlah 27 orang atau $27 \%$. Maka rata-rata para responden menjawab benar atau tahu pada pernyataan wisata syariah mengharamkan membawa minuman berakohol atau barang yang diharamkan dalam Islam.

Berdasarkan relasi dengan masyarakat

Pada angket no. 20 yang menjawab benar atau tahu berjumlah 66 orang atau $66 \%$, kemudian yang menjawab salah/tidak tahu berjumlah 34 orang atau $34 \%$. Maka rata-rata para responden menjawab benar atau tahu pada pernyataan interaksi dalam wisata syariah berdasarkan prinsipprinsip syariah.

Pada angket no. 21 yang menjawab benar atau tahu berjumlah 88 orang atau $88 \%$, kemudian yang menjawab salah/tidak tahu berjumlah 12 orang atau 12\%. Maka rata-rata para responden menjawab benar atau tahu pada pernyataan wisata syariah menetapkan batas muhrim bagi para wisatawan.

\section{Berdasarkan dimensi agenda perjalanan}

Pada angket no. 22 yang menjawab benar atau tahu berjumlah 88 orang atau $88 \%$, kemudian yang menjawab tidak tahu berjumlah 12 orang atau $12 \%$. Maka rata-rata para responden menjawab benar atau tahu pada pernyataan agenda perjalanan dalam wisata syariah tidak mengganggu waktu beribadah. .

Pada angket no. 23 yang menjawab benar atau tahu berjumlah 94 orang atau 94\%, kemudian yang menjawab salah/tidak tahu berjumlah 6 orang atau 6\%. Maka rata-rata para responden menjawab benar atau tahu pada pernyataan rute yang telah ditetapkan berjalan sesuai dengan rencana yang telah ditetapkan.

Berdasarkan hasil penelitian di atas dapat diketahui bahwa pengetahuan masyarakat Kota Pekanbaru tentang wisata syariah dikatakan sangat kuat dengan persentase 83,86\%, pengetahuan masyarakat Kota Pekanbaru dengan mendefinisikan, menguraikan, mengidentifikasi, menyebutkanm serta menyatakan dari objek, tujuan, target, guide, fasilitas, kuliner, relasi, agenda yang diterapkan dalam wisata syariah.

\section{Hasil Uji Instrumen Uji Validitas}

Uji validitas yaitu uji dengan menggunakan rumus Corrected Item Total dengan taraf signifikan sebesar $5 \% \quad(\alpha=0,05 \%)$ artinya suatu pernyataan dianggap valid jika berkorelasi bersignifikan terhadap skor total (Dwi Priyatno, 2016 : 59).

Dari hasil penelitian terhadap indikator setiap variabel dalam penelitian ini semuanya valid. Indikator setiap variabel signifikan terhadap topik yang diteliti. Berikut hasil dari pengujian validitas untuki item-item variabel 
analisis pengetahuan masyarakat Kota Pekanbaru tentang wisata syariah.
Berikut ini disajikan tabel tentang hasil uji validitas dan butir-butir pernyataan responden penelitian.

Tabel 4

Hasil Uji Validitas

\begin{tabular}{|c|c|c|c|}
\hline \multirow[b]{2}{*}{ Item Pernyataan } & \multicolumn{2}{|c|}{ Validitas } & \multirow[b]{2}{*}{ Keterangan } \\
\hline & $\begin{array}{l}\text { Corrected item total } \\
\text { correlation }\end{array}$ & $\begin{array}{l}\text { nilai } r=0.165(\mathrm{~N}= \\
100)\end{array}$ & \\
\hline Item 1 & 0.738 & 0,202 & Valid \\
\hline Item 2 & 0.309 & 0,202 & Valid \\
\hline Item 3 & 0.729 & 0,202 & Valid \\
\hline Item 4 & 0.688 & 0,202 & Valid \\
\hline Item 5 & 0.632 & 0,202 & Valid \\
\hline Item 6 & 0.699 & 0,202 & Valid \\
\hline Item 7 & 0.258 & 0,202 & Valid \\
\hline Item 8 & 0.710 & 0,202 & Valid \\
\hline Item 9 & 0.385 & 0,202 & Valid \\
\hline Item 10 & 0.322 & 0,202 & Valid \\
\hline Item 11 & 0.266 & 0,202 & Valid \\
\hline Item 12 & 0.699 & 0,202 & Valid \\
\hline Item 13 & 0.350 & 0,202 & Valid \\
\hline Item 14 & 0.317 & 0,202 & Valid \\
\hline Item 15 & 0.362 & 0,202 & Valid \\
\hline Item 16 & 0.332 & 0,202 & Valid \\
\hline Item 17 & 0.261 & 0,202 & Valid \\
\hline Item 18 & 0.239 & 0,202 & Valid \\
\hline Item 19 & 0.738 & 0,202 & Valid \\
\hline Item 20 & 0.642 & 0,202 & Valid \\
\hline Item 21 & 0.224 & 0,202 & Valid \\
\hline Item 22 & 0.262 & 0,202 & Valid \\
\hline Item 23 & 0.250 & 0,202 & Valid \\
\hline
\end{tabular}

Dari tabel di atas dapat dilihat bahwa semua indikator variabel dapat dikatakan valid karena, jika $r_{\text {hitung }}>r_{\text {tabel }}$ maka item-item pernyataan dikatakan valid.

Diketahui nilai $r_{\text {tabel }}$ dengan taraf signifikan 5\% $(\alpha=0,05)$ adalah sebesar 0,202 (lihat $r$ tabel) dan nilai ini dibandingkan dengan niloai $r$ hitung. Nilai $r$ hitung dalam uji validitas ini adalah pada kolom Item Total Statistic (Corrected Item-Total). Dan dari tabel di atas menunjukan bahwa butir pernyataan tersebut sinyatakan valid.

\section{Uji Reliabilitas}

Batasan nilai dalam uji reliabilitas adalah 0.6 (lihat $r$ tabel). Jika nilai reabilitas kurang dari 0,6 maka nilai kurang baik. Nilai reliabilitas dalam uji ini adalah pada kolom Reliability Statistic (Cronbach's Alpha) (Dwi Priyatno, 2016 : 60).

Berikut ini disajikan tabel tentang hasil uji reliabilitas dari butir-butir pernyataan responden penelitian: 
Tabel 5

Hasil Uji Reliabilitas

\begin{tabular}{cccc}
\hline \multirow{2}{*}{$\begin{array}{c}\text { Item } \\
\text { Pernyataan }\end{array}$} & Cronbach alpha & $\begin{array}{c}\text { Cronbach's } \\
\text { Alpha }\end{array}$ & Keterangan \\
\cline { 2 - 3 } & 0.872 & 0.6 & Reliabel \\
\hline Item 1 & 0.886 & 0.6 & Reliabel \\
\hline Item 2 & 0.873 & 0.6 & Reliabel \\
\hline Item 3 & 0.874 & 0.6 & Reliabel \\
\hline Item 4 & 0.876 & 0.6 & Reliabel \\
\hline Item 5 & 0.874 & 0.6 & Reliabel \\
\hline Item 6 & 0.886 & 0.6 & Reliabel \\
\hline Item 7 & 0.874 & 0.6 & Reliabel \\
\hline Item 8 & 0.883 & 0.6 & Reliabel \\
\hline Item 9 & 0.885 & 0.6 & Reliabel \\
\hline Item 10 & 0.886 & 0.6 & Reliabel \\
\hline Item 11 & 0.874 & 0.6 & Reliabel \\
\hline Item 12 & 0.884 & 0.6 & Reliabel \\
\hline Item 13 & 0.885 & 0.6 & Reliabel \\
\hline Item 14 & 0.884 & 0.6 & Reliabel \\
\hline Item 15 & 0.885 & 0.6 & Reliabel \\
\hline Item 16 & 0.886 & 0.6 & Reliabel \\
\hline Item 17 & 0.886 & 0.6 & Reliabel \\
\hline Item 18 & 0.872 & 0.6 & Reliabel \\
\hline Item 19 & 0.876 & 0.6 & Reliabel \\
\hline Item 20 & 0.887 & 0.6 & Reliabel \\
\hline Item 21 & 0.887 & 0.6 & Reliabel \\
\hline Item 22 & 0.886 & 0.6 & \\
\hline Item 23 & & & \\
\hline
\end{tabular}

\section{Uji Hipotesis (One Sample Test)}

Uji (t-test) menggunakan satu sampel ini tergolong hipotesis deskriptif. Hipotesis deskriptif adalah memiliki tujuan pembanding atau komparasi, apakah rata-rata satu populasi maupun beberapa populasi memiliki perbedaan secara signifikan. Selain itu t-test satu sampel dapat dipergunakan dalam pengujian data nilai berbeda secara nyata atau sama maupun tidak sama dengan rata-rata sampel. 
Tabel 6

Hasil Uji Hipotesis (One-Sample Test)

\begin{tabular}{|c|c|c|c|c|c|c|}
\hline & \multirow[b]{2}{*}{$\mathrm{t}$} & \multirow[b]{2}{*}{$\mathrm{df}$} & \multirow[b]{2}{*}{$\begin{array}{c}\text { Sig. } \\
\text { (2-tailed) }\end{array}$} & \multirow[b]{2}{*}{$\begin{array}{c}\text { Mean } \\
\text { Difference } \\
\end{array}$} & \multicolumn{2}{|c|}{$\begin{array}{c}95 \% \text { Confidence Interval } \\
\text { of the Difference }\end{array}$} \\
\hline & & & & & Lower & Upper \\
\hline $\begin{array}{l}\text { Pengetahuan } \\
\text { masyarakat }\end{array}$ & 44.958 & 99 & .000 & 19.290 & 18.44 & 20.14 \\
\hline
\end{tabular}

Berdasarkan tabel 15 di atas, analisis data menggunakan uji one sample test menggunakan SPSS, pada hasil data olahan yang peneliti buat di dapat tabel one sample test dimana pada tabel tersebut didapat hasil Mean/rata-rata nilai pada 19.29 dengan standar deviasi (SD) 4,291 dengan jumlah sampel 100. Nilai mean akan kita gunakan untuk melihat berapa nilai tertinggi dan terendah hasil uji $\mathrm{t}$ dengan tingkat probabilitas 95\%.

Pada tabel One sample Test, didapat nilai t hitung sebesar 44,958 dengan probabilitas sig, (2-tailed) sebesar 0.000. Dengan sampel N sebanyak 100 dengan probability a $5 \%$ didapat nilai t tabel sebesar 1,6605. Karena nilai $t$ hitung $(44,958)>t$ tabel $(1,6605)$ maka dapat disimpulkan bahwa hipotesa dalam penelitian ini diterima.

Jadi, pengetahuan masyarakat Kota Pekanbaru tentang wisata syariah paling rendah berada pada interpretasi $61 \%$ - 80\% dalam kategori " kuat atau mengetahui dari rata-rata nilai ideal itu benar bahkan lebih dari 61\% - 80\% yang selama ini diduga oleh peneliti.

\section{SIMPULAN}

Berdasarkan dari hasil pembahasan yang telah diuraikan pada bab-bab terdahulu yang membahas analisis pengetahuan masyarakat Kota Pekanbaru tentang wisata syariah, maka peneliti dapat mengembil kesimpulan sebagai berikut: Berdasarkan hasil interpretasi skor dan hipotesa, pengetahuan masyarakat Kota Pekanbaru tentang wisata syariah tergolong sangat kuat dan mengetahui tentang apa itu wisata syariah yang dapat dilihat dari delapan dimensi yaitu: objek, tujuan, target, guide, fasilitas ibadah, kuliner, relasi dengan masyarakat, dan agenda perjalanan.

Berdasarkan hasil penelitian di atas, penulis memberikan beberapa saran yaitu sebagai berikut: (1) Perlunya sosialisasi konsep dan model wisata syariah kepada masyarakat oleh para pemangku kepentingan; (2) Perlunya sosialisasi pentingnya wisata syariah bagi destinasi wisata seperti perhotelan. Kuliner, transportasi, guide, dan frasilitas lainnya; (3) Sebaiknya dalam penyelenggaraan wisata syariah di Kota Pekabaru tetap menerapkan prinsip syariah yang diselaraskan dengan budaya melayu; (4) Meningkatkan peran para pemangku kepentingan seperti Pemerintah Kota Pekanbaru, LAM Pekanbaru, BPOM, DSN-MUI, PHRI dan Dinas Pariwisata dalam penyelenggaraan wisata syariah; (5) Meningkatkan fasilitas wisata yang sesuai dengan standar syariah yang 
telah ditetapkan fatwa DSN-MUI tentang pedoman penyelengaraan pariwisata berdasarkan prinsip syariah; (6) Semua pemangku kepentingan, terutama para praktisi wisata syariah hendaknya melakukan promosi yang lebih baik, agar meningkatkan minat para wisatawan untuk berkunjung ke wisata syariah; dan (7) Masyarakat hendaknya menginplementasikan konsep wisata untuk menjadi tuan rumah yang baik bagi wisatawan dan mampu mendatangkan wisatawan yang ingin berkunjung ke Kota Pekanbaru.

\section{DAFTAR RUJUKAN}

Al- Qur'an. Departemen Agama RI, AlQur'an dan Terjemah. Surabaya: CV. Penerbit Fajar Mulya, 2003.

Alim, Haidar Tsani. 2014. Analisis Potensi Pariwisata Syariah Dengan Mengoptimalkan Industri Kreatif di Jawa Tengah dan Yogyakarta: Semarang.

Ariniro ,Rofi'i. 2016. Panduan Wisata Religi Ziarah Wali Sanga. Yogyakarta: Saufa.

Assegaf, Abd. Rachman. 2011. Filsafat Pendidikan Islam,Jakarta:Raja Grafindo Persada.

Bagyono. 2014. Pariwisata dan Perhotelan. Bandung: Alfabeta.

Bahammam, Fahad Salim. 2011. Panduan Wisatawan Muslim,Jakarta Timur: Pustaka AlKautsar.

Bawazir ,Tohir. 2013. Panduan Praktis Wisata Syariah,Jakarta: Pustaka Al-Kautsar.

Chookaew, Sureerat. 2015. Incresiang Halal Tourims Potential at Andaman Gulf in Thailand for Muslim Country. The Journal of Economic, Business and Managemet. Vol 3.
Departemen Pendidikan Nasional. 2008. Kamus Besar Bahasa Indonesia, Jakarta:PT. Gramedia Pustaka.

Fitriani, Sinta. 2011. Promosi Kesehatan, Yogyakarta: Graha Ilmu.

Ismawati, Esti. 2012. IImu Sosial Budaya Dasar. Yogyakarta: Ombak.

Kementrian Pariwisata. 2015. Laporan Akhir Kajian Pengembangan Wisata Syariah, Jakarta.

Muhammad. 2008. Metodologi Penelitian Ekonomi Islam. Jakarta: Raja Wali Pers.

Pradja, Juhaya S., 2012. Ekonomi Syariah. Bandung:Pustaka Setia.

Priyadi, Unggul. 2016. Pariwisata Syariah Prosepek dan Pengembangan. Yogyakarta: UPP STIM YKPN.

Priyanto, Duwi. 2016. SPSS Handbook Analisis Data, Olah Data, \& Penyelesaian Kasus-kasus Statistik. Jakarta: Mediakom.

Purwanto, Ngalim. 2007. Ilmu Pendidikan Teoretis dan Praktis, Bandung:PT. Remaja Rosdakarya.

Purwanto. 2011. Evaluasi Hasil Belajar. Yogyakarta: Pustaka Belajar.

Ramli, Ahmad Fathoni. 2016. Prinsipprinsip Perasuransian Syariah dan penerapannya di Indonesia. Sukabumi: Yayasan Ama Sosial Mencerdaskan Insan Agar Hidup Mandiri, Adil dan Demokratis.

Ridwuan. 2014. Dasar-Dasar Statistika. Bandung: Alfabeta.

Riau Tourism Board. 2014. Visit Riau Informasi dan Panduan Wisata Riau, Pekanbaru: Wonderful Indonesia.

Sanusi, Anwar. 2016. Metodologi Penelitian Bisnis. Jakarta: Salemba Empat.

Sucipto, Hery dan Andayani, Fitria. 2014. Karakter, Potensi, Prospek, 
dan Tantangannya Wisata Syariah. Jakarta:Grafindo.

Sudjana, Nana. 2008. Penilaian Hasil Proses Belajar Mengajar. Bandung: Rosdakarya.

Santoso, Singgih. 2016. Panduan Lengkap SPSS Versi 23. Jakarta: PT Elex Media Kompotindo.

Sugiyono. 2015. Metode Penelitian Kuatitatif, Kualitatif, dan $R \& D$, Bandung: CV. Alfabeta.
Suherlan, Ade. 2015. Persepsi Msyarakat Jakarta Terhadap Wisata Syariah. The Journal of Tauhidinomics. Vol. 1, Jakarta: Fakultas Ekonomi dan Bisnis UIN Syarif Hidayatullah.

Widagdyo, Kurnia Gilang. 2015. Analisis Pasar Wisata Halal Indonesia. The Journal of Tauhidinomics Vol. 1, Jakarta:Universitas Sahid. 